\title{
A IMAGEM DO ETANOL COMO "DESENVOLVIMENTO SUSTENTÁVEL” E A (NOVA) MORFOLOGIA DO TRABALHO
}

\author{
Maria Aparecida de Moraes Silva* \\ Lúcio Vasconcellos de Verçoza ${ }^{* *}$ \\ Juliana Dourado Bueno***
}

\begin{abstract}
O objetivo deste texto é a análise das relações e condições de trabalho nos canaviais, resultantes do processo de reconfiguração do trabalho, em face do momento atual, caracterizado pela intensificação do processo de mecanização do corte de cana. Em função da rapidez das mudanças ocorridas no processo de trabalho, considera-se que estas relações de trabalho devam ser analisadas no contexto da imagem do "desenvolvimento sustentável" produzida pelas empresas sucroalcooleiras e pelo Estado brasileiro. A intensificação da exploração da força de trabalho no quadro de uma (nova) morfologia combina, de um lado, tecnologias altamente avançadas, e, de outro, aumento da desqualificação da força de trabalho. As reflexões procurarão trazer à superfície a realidade social escondida atrás da ideologia fabricada para sustentar essa atividade econômica. Visa-se a uma análise crítica da ideologia desenvolvimentista inerente a essa produção. A metodologia empregada baseia-se na história oral e observação direta nos canaviais paulistas e alagoanos.

Palavras-CHAVE: Relações de trabalho. Condições de trabalho. Capitalismo no campo. Cana-deaçúcar.
\end{abstract}

\section{INTRODUÇÃO}

Os estudos sobre a produção açucareira no Brasil remontam ao início da colonização portuguesa no século XVI. De lá para cá, cronistas, pintores, biólogos, viajantes, literatos, sociólogos, economistas, historiadores, cineastas, inter allia, registraram suas análises e impressões sobre a vida social, política, cultural e econômica derivada dessa produção ao longo dos cinco séculos de história. Essa cultura, aliada à exploração de outros recursos naturais - pedras preciosas - formaram a base da colonização, que contribuiu para o processo de acumulação primitiva do capitalismo europeu, por meio, não somente da apropriação dos excedentes produzidos pela colônia, como, também, pela sus-

* Doutora em Sociologia. Professora livre-docente aposentada da UNESP. Professora visitante do Departamento de Sociologia da Universidade Federal de São Carlos UFSCAR.

Rua Alvarenga Peixoto, 55 Ap/11. Parque Arnold Schimidt. Cep: 13566-582 São Carlos - São Paulo - São Paulo.maria_moraes@terra.com.br.

* * Doutorando do Programa de Pós-Graduação em Sociologia da UFSCAR. luciovercoza@yahoo.com.br

* * * Doutoranda do Programa de Pós-Graduação em Sociologia na UFSCAR. julidourado@uol.com.br tentação do comércio de escravos.

A face atual do Brasil, sobretudo desde o último meio século, vem sendo, em boa parte, matizada pelas gigantescas áreas cobertas com canade-açúcar, não mais denominada matéria-prima destinada à metrópole, mas commodity, destinada aos mercados globais, segundo a lógica da acumulação do capitalismo contemporâneo, no contexto do novo imperialismo, segundo Harvey (2004). Se, no passado colonial, os canaviais concentravamse na Zona da Mata nordestina, atualmente, a maioria deles se localiza na região Centro-Sul, sobretudo no território paulista, responsável por quase dois terços de toda a produção do país. ${ }^{1}$ São perto

${ }^{1}$ Em 1997, foram exportadas 3.844.224 toneladas de açúcar. Dez anos depois, em 2007, este montante passou para 12.223.221, havendo um acréscimo de quase quatro vezes (IEA, 2009). Segundo dados do MAPA (Ministério da Agricultura, Pecuária e Abastecimento), em 2012, houve acréscimo de $57,5 \%$ na quantidade de etanol exportada, passando de 1,57 para 2,48 milhões de toneladas. No que tange à produção, na safra de 2005-2006, foram 15.808.184.000 de litros e, em 2010-2011, este montante subiu para 25.780.404.000, portanto, havendo um acréscimo de quase $70 \%$, num período de apenas cinco anos. Quanto à produtividade, segundo dados da UNICA (União da Indústria Canavieira), em 1976, era necessária uma tonelada de cana para produzir 45 litros de álcool. Em 2004, esse montante passa para 75 litros, 
de seis milhões de hectares distribuídos ao longo das bacias hidrográficas e das águas subterrâneas dos aquíferos que atravessam essa região. Se, no passado colonial, o açúcar era o produto fundamental, hoje, além dele, o etanol utilizado como combustível constitui-se, não somente em mercadoria, cuja finalidade é movimentar os automóveis flex fluel, como, também, na ideologia do combustível limpo, sustentável, que vem sendo paulatinamente fabricada pelo Estado, visando contemplar os interesses de capitais nacionais e internacionais em busca de lucros e apropriação da renda da terra (incluindo as águas). ${ }^{2}$ Trata-se, portanto, de um processo de territorialização do capital, cujas fronteiras estão delimitadas pelos recursos naturais - terra e água - e pela ação do Estado para garantir, não apenas a logística dessa produção - estradas, alcoodutos, portos -, como, também, os subsídios por meio de empréstimos vultosos para a instalação de usinas e financiamento da produção agrícola em geral (Xavier et al., 2012). E mais ainda. A criação de normativas institucionais para regular o mercado e as relações de trabalho, sobretudo na agricultura, analisada mais adiante.

Na conferência Rio-92, oficializou-se a noção de “desenvolvimento sustentável”, definida no Relatório Brundtland, em 1987, como paradigma para o desenvolvimento socioeconômico aliado à conservação dos recursos naturais. O Estado brasileiro e outros países signatários da Agenda 21 Global se comprometeram a adotá-la como orientação para suas políticas de desenvolvimento (Teixeira, 2005, p. 53). Levando-se em conta os problemas advindos da expansão produtiva do capitalismo em várias partes do globo, vários estudos têm mostrado que as práticas relacionadas à

havendo um aumento de 64\% (www.unica.com.br acesso em 30/11/2012). Dentre os estados nordestinos, Alagoas é o maior produtor de cana-de-açúcar. Na safra de 2011/12, foram 27.705 milhões de toneladas; em São Paulo esse montante chegou a 304.230 milhões, segundo dados da UNICA. No que diz respeito ao conjunto do país, foram 551.215 milhões de toneladas (www.unica.com.br. Acesso em 03/04/2013).

${ }^{2}$ Para produzir um litro de etanol são necessários 13 litros de água (considerando-se apenas a parte industrial do processo produtivo). depredação ambiental se chocam com as normativas dessa Agenda institucional. Nos limites deste artigo, não nos cabe adentrar o debate sobre o conceito e ou noção de "desenvolvimento sustentável". Teixeira (2005) faz um balanço desse debate, ressaltando o confronto entre os ambientalistas e os chamados desenvolvimentistas, apoiados na lógica do crescimento econômico, que veem a conservação ambiental e a sustentabilidade como obstáculos. Por outro lado, há autores que criticam o conceito de “desenvolvimento sustentável”. Segundo Leis (1999, p. 159, apud Teixeira, p. 54), o conceito de "desenvolvimento sustentável” faz parte de um processo de "[...] adoção oportunista e instrumental [...]” por parte dos estados e das empresas, de novos valores trazidos pelo ambientalismo, com o objetivo de garantir a continuidade do sistema produtivo. Nesse caso, haveria um processo de cooptação das noções do ambientalismo para justificar a lógica produtivista atual.

Para além da noção de "desenvolvimento sustentável”, o discurso do desenvolvimento, em sua concepção mais ampla, tem pautado a discussão sobre a agricultura em diferentes momentos histórico-sociais no Brasil e também no contexto internacional. No Brasil, alguns setores da agricultura foram apresentados como verdadeiros motores do desenvolvimento: isso ocorreu no período da chamada "agricultura moderna”, e também a partir da década de 1980, com a ascensão da “agroindústria” e dos Complexos Agroindustriais - CAI. Estes podem ser caracterizados pela expansão da participação do capital internacional, participação do Estado nas políticas de terras, inovações tecnológicas, pesquisas e implantação de infraestrutura local e presença de grandes grupos empresariais e empresas multinacionais (Heredia et al., 2010).

No que diz respeito, especificamente, à agroindústria canavieira, o discurso do desenvolvimento promovido pelo setor foi e tem sido bastante acentuado. Silva et al. (2013) demonstram que o Estado tem um papel fundamental na manutenção desse discurso, na garantia dos padrões de acumulação dos capitais nacionais e internaci- 
onais e na construção de uma nova "ideologia do etanol”. O Estado conta com a colaboração de empresários, representantes dos trabalhadores e meios de comunicação para difundir essa ideologia. A nova imagem revela os números gigantescos da produção, mas esconde a degradação socioambiental e as formas de superexploração dos trabalhadores. ${ }^{3}$

No que tange ao aspecto político, o agribusiness tem sido o símbolo do desenvolvimento econômico do país, por meio do saldo positivo do comércio exterior, graças ao aumento das exportações, sobretudo de produtos agrícolas, que vem garantindo, especialmente nos últimos anos, o saldo positivo da balança comercial do país. ${ }^{4}$

É importante destacar que a lógica desenvolvimentista, ao evidenciar as questões ambientais, procura apagar a situação laboral, na medida em que a tecnologia pressupõe o emprego de máquinas tão somente. Essa evidência se manifesta no caso brasileiro nos sítios das empresas canavieiras, nos quais as imagens veiculadas são as das grandes máquinas colheitadeiras, onde os operadores das mesmas não aparecem, bem como os locais onde estão os cortadores manuais, cobertos pela fuligem da cana queimada. Por outro lado, tais imagens são ancoradas em normativas institucionais que asseguram ou a invisibilidade dos trabalhadores ou a visibilidade dos mesmos inseridos em relações laborais "sustentáveis" soci-

${ }^{3}$ A construção da ideologia carregada de elementos simbólicos foi analisada por Burke (2009), referenciando-se à fabricação da imagem do poder absoluto do rei Luiz XIV. Em artigo recente, Bruno (2012) utiliza essa noção para analisar o habitus das elites agrárias do Brasil por meio da propaganda midiática SOU AGRO. A "fabricação dessa imagem” está presente na letra do samba-enredo da campeã do carnaval do Rio de Janeiro de 2013, Vila Izabel, patrocinada pela BASF, uma das maiores vendedoras de agrotóxicos no Brasil. A homenagem aos agricultores (familiares?) é sem dúvida uma forma de confundir e dissimular a maneira de produzir das grandes empresas do agribusiness. A imagem simbiótica do samba-agricultura é mais uma empreitada das elites para assegurar suas vendas no exterior, além de cooptar um dos traços mais importantes da cultura popular.

${ }^{4}$ Em recente artigo, Roberto Rodrigues (ministro da Agricultura do governo Lula) defendendo a melhoria dos portos para escoamento dos grãos, sobretudo da soja, afirmou que a exportação do agronegócio passou de 24,8 bilhões de dólares em 2002 para 95,2 em 2012, quase quatro vezes mais. Sua tese, "meu porto, minha vida” é a de que essa melhoria traria benefícios não somente para os produtores como também para todos os brasileiros (Folha de S. Paulo Tendências/Debates, 29 de mar. 2013, p.3). al e ambientalmente.

Quanto à degradação socioambiental, muitos estudiosos já apontaram os efeitos negativos desse monocultivo (Szmrecsány, 1994; Andrade, 2009; Thomaz Jr, 2009; Silva e Martins, 2010). Além dos males causados pela queimada de cana (Bosso, 2006; Ribeiro, 2008; Ribeiro, Pesqueiro, 2010, dentre outros), há aqueles relacionados a outras fases do processo produtivo da cana, sem contar que os milhares de veículos empregados nessa atividade - caminhões, tratores, máquinas colhedeiras, ônibus para o transporte dos trabalhadores etc. - são todos movidos à energia derivada dos combustíveis fósseis. Ainda que tenha havido o crescimento da mecanização e a proibição das queimadas a partir de 2017 (no estado de São Paulo), ${ }^{5}$ nota-se que essa prática ainda continua, pois, ao queimar a palha da cana, diminui-se em $50 \%$ a quantidade de água do caule, resultando em menores custos advindos do transporte e das operações industriais da transformação da cana em açúcar ou etanol. Outra fonte de poluição reporta-se à utilização do resíduo gerado no processo de destilação do etanol - vinhoto ou vinhaça como fertilizante. A cada litro de etanol, são produzidos de 10 a 18 litros de vinhoto, espalhados nos canaviais sob o sistema de fertirrigação. Estudos apontam que o poder poluente desse resíduo chega a ser cem vezes maior do que o esgoto doméstico, além dos danos provocados pela alta temperatura ao sair dos destiladores (70 a 80 graus) que, ao ser lançado no solo, torna-se prejudicial à fauna, flora, microfauna, além de contaminar as águas subterrâneas, quando utilizado em grandes quantidades e, sobretudo, durante as chuvas (Plácido Jr. et al., 2007; Xavier et al., 2012, p. 44). A parte que não é utilizada como fertilizante é depositada diretamente no solo. Em décadas passadas, esse subproduto era lançado nos rios, provocando o desaparecimento de muitas espécies de pei-

${ }^{5}$ Em junho de 2007, o governo do estado de São Paulo firmou com a UNICA o Protocolo Agroambiental visando ao fim das queimadas até o ano de 2014 nas áreas mecanizáveis e 2017 nas não mecanizáveis. Houve a adesão de 127 usinas e 23 associações de fornecedores de cana. Disponível em: http://homologia.ambiente.sp. gov.br/estanolverde/listas.asp. Acesso em 28 de mar. 2010. 
xes, sobretudo no estado de São Paulo.

No intuito de desfazer o mito do etanol como combustível limpo, o estudo de Cardoso et al. (2008) revela que o nitrogênio ativo com atividade química e biológica possui potencial para modificar as propriedades físicas do ambiente ou da biota, pelos seguintes mecanismos: a) arraste pela água de chuva do nitrogênio contido nos adubos; b) ação de microrganismos no solo, transformando parte do adubo em gases; c) produção de nitrogênio ativo por bactérias existentes em raízes de leguminosas, que transforma o nitrogênio inerte do ar em nitrogênio ativo; d) formação de gases nitrogenados como produto da combustão de qualquer combustível.

As considerações precedentes compõem um dos retratos da produção sucroenergética brasileira e visam desmistificar a imagem de energia limpa, sustentável, exportada para o mundo globalizado e também para os consumidores internos. Outro aspecto da insustentabilidade dessa produção, pouco levada em conta em muitos estudos, reporta-se à acumulação por espoliação por meio da ocupação das terras. A fim de aprofundar nossas reflexões sobre o conceito de acumulação por espoliação, abordaremos, nos próximos itens, o caso recente da ocupação de terras pela agroindústria canavieira alagoana e a destruição das florestas de babaçu no Maranhão.

\section{ACUMULAÇÃO POR ESPOLIAÇÃO NAS TERRAS ALAGOANAS}

Segundo Lima (2006, p. 101), a evolução da agroindústria canavieira alagoana, entre o período de construção do Instituto do Açúcar e do Álcool - IAA até 1990 está constituída por três etapas: “[...] a da consolidação do parque usineiro (1930-1950), a do processo de expansão e modernização (1950-1975) e a de um segundo surto expansivo ligado ao Proálcool (1975-1989)”. De acordo com o mesmo autor, no que tange a todo esse longo período, a decisão de expandir as lavouras de cana para os tabuleiros (na década de 1950) foi o fato "mais importante para moldar a estrutura produtiva alagoana” (idem, p.101). Mas o que são os tabuleiros? Por que eles foram tão decisivos para os rumos da agroindústria canavieira alagoana?

O geógrafo Manuel Correia de Andrade (1959) descreve os tabuleiros como zonas que se estendem desde o pediplano de Arapiraca (município localizado no Agreste Alagoano) até as formações do litoral, possuindo em Alagoas muito maior largura do que em Pernambuco. "Acha-se inclinada, grosso modo, em direção ao mar, alcançando quase $200 \mathrm{~m}$ de altitude a Oeste de Arapiraca, para descer até os 40 ou $50 \mathrm{~m}$ nas proximidades da praia onde forma abruptas falésias" (p. 24).

A subida dos canaviais alagoanos para os tabuleiros (até o início da década de 1950 os canaviais eram tradicionalmente concentrados nas várzeas dos vales úmidos) está relacionada a um conjunto de fatores que acarreta economia para a usina, como: "por ser plano, é o tabuleiro menos atingido pela erosão, facilitando, por conseguinte, a mecanização, o tratamento e a colheita da lavoura [...]; nos tabuleiros as canas suportam melhor a estiagem, são mais uniformes e menos sujeitas a doenças.” (Idem, ibidem, p. 56). A iniciativa pioneira foi da usina Sinimbu que, por meio de uma adubação adequada, logrou êxito na incorporação dos tabuleiros (Andrade, 1959 e 1994; Loureiro, 1969; Sant'Ana, 1970). Essa experiência bem sucedida (do ponto de vista do usineiro) foi seguida por outras usinas do estado. Assim, os tabuleiros possibilitaram uma drástica expansão da fronteira agrícola da cana, sendo hoje a principal área produtora dessa cultura em Alagoas.

Apesar de as áreas dos tabuleiros se estenderem do Rio Grande do Norte ao estado de Sergipe (Andrade, 1994), elas se destacam em Alagoas por serem, em geral, mais largas e compridas, quando comparadas às dos outros estados. No entanto, elas não são homogêneas: ao sul de Alagoas, os tabuleiros se caracterizam por sua maior dilatação de largura e profundidade, enquanto ao norte, são menos extensos (Lima, 2006). Por isso, atualmente a maior concentração de usinas de Alagoas está na microrregião dos tabuleiros de São Miguel dos 
Campos, ao sul do estado. ${ }^{6}$

Consideramos que essa breve contextualização do papel dos tabuleiros na expansão dos canaviais seja fundamental para compreendermos por que, atualmente, Alagoas é líder nordestina de produção dessa matéria-prima. Todavia, é impossível compreender tal liderança se nos limitarmos apenas às potencialidades dos aspectos geográficos. Por trás do período "de expansão e modernização” (Lima, 2006) dessa agroindústria em Alagoas, estão, dentre múltiplos aspectos, vários episódios de expropriação. Comecemos investigando as expropriações dos pequenos produtores.

No livro Açúcar: notas e comentários, Osman Loureiro, que foi usineiro e ex-governador do Estado, comete um "ato falho" ao revelar aquilo que ele próprio queria esconder. Vejamos o seguinte trecho:

A esta primeira primazia quanto à posse de trecho geográfico especial, é preciso adir-se a zona dos chamados tabuleiros [...] esses altiplanos, tidos e havidos de velha data como impróprios à cultura da cana, e apenas admitindo as pequenas lavouras de subsistência, como a mandioca, a batata e algumas frutas, serviam, entretanto, por igual, para a grande lavoura. Tudo era contemperá-los [sic] com adubação adequada. As experiências, por eloqüentes, tiveram seguidores. Em breve, vastos canaviais começaram a desertar-se por esses chapadões, outrora relegados por inadequados, e hoje avocados ao serviço de nossa cultura maior. [...] Para quem atravessou essas solidões semidesérticas e hoje entresachadas [sic] de vigorosos canaviais, o coração se lhe desaperta na antevisão do futuro que nos aguarda (Loureiro, 1969, p. 244 e 245, grifos nossos).

Nessa passagem, Loureiro descreve os tabuleiros de duas formas: a primeira é como área das pequenas lavouras de subsistência, enquanto a segunda é como espaço das solidões semidesérticas. Ora, se esses espaços admitiam as pequenas lavouras de subsistência como poderiam ser solidões semidesérticas? Então, era insignificante o número de pequenos produtores nessas áreas? Essa questão é de suma importância, pois, se aceitar-

${ }^{6}$ A microrregião dos Tabuleiros de São Miguel dos Campos é formada pelos seguintes municípios: São Migue dos Campos, Roteiro, Jequiá da Praia, Boca da Mata, Campo Alegre, Anadia, Junqueiro, Teotônio Vilela e Coruripe. mos a premissa das solidões semidesérticas, a expropriação dos pequenos produtores nessas áreas teria sido quase nula. Por outro lado, recusando essa premissa - e adotando a de que seriam áreas ocupadas por pequenas lavouras de subsistência -, a vertiginosa expansão da cana nos tabuleiros só poderia ter ocorrido por meio de um "xeque mate" nos pequenos produtores.

Heredia (2008) foi a pesquisadora que se aprofundou de forma mais minuciosa nessa temática, em estudo realizado no fim da década de 1970 e início dos anos 1980, que incluía pesquisas de campo em parte da área que deu origem ao município de Teotônio Vilela (situado na microrregião dos tabuleiros de São Miguel dos Campos). A autora mostra que os pequenos produtores, inclusive os proprietários, faziam uso dessas áreas situadas fora da grande propriedade, denominando-as terras de "hereu" ou "terras sem donos", onde plantavam para a sua subsistência e essa prática passou para as distintas gerações (Heredia, 2008, p. 60).

Nessa pesquisa, Heredia conseguiu reunir diversos depoimentos, além de outras evidências que comprovam que a expansão da cana para os tabuleiros só foi possível por meio da expropriação dos pequenos produtores. ${ }^{7}$ Dentre os mecanismos de expropriação identificados pela autora, destacamos os seguintes: 1) boatos de que os usineiros tomariam as terras daqueles que não tinham o documento que comprovasse a posse resultaram em vendas de terras por um preço muito

${ }^{7}$ Conforme o Censo agrícola de 1920, no município de Coruripe (que faz fronteira com Teotônio Vilela), as lavouras do coco (1.217 ha.), de feijão, milho e mandioca (1.102 ha.) ocupavam uma área plantada superior à da cana-de-açúcar (863 ha.) (Heredia, 1988, p. 49). Noventa anos após o Censo de 1920, a área do plantio de feijão, milho e mandioca foi reduzida pela metade (restando, atualmente, o equivalente a 650 ha, segundo levantamento das lavouras do IBGE em 2009), enquanto a da cana-de-açúcar cresceu vertiginosamente, de 863ha para 52.238 ha. No tocante à produção agrícola do município de Teotônio Vilela, segundo o levantamento do IBGE sobre as lavouras (realizado 2009), a plantacão de cana-deaçúcar é líder, com aproximadamente 1 milhão de toneladas de cana colhidas numa área plantada de 15.500 hectares. A esmagadora liderança só se torna evidente quando comparamos esses números com os dos cultivos de outros produtos: o que mais se aproxima da cana-de-açúcar é o do feijão, que ocupa apenas 200 hectares de área plantada, seguida do milho, com 100 hectares e da mandioca, com inexpressivos 55 hectares de área plantada. 
abaixo do valor de mercado; 2) as usinas compravam o lote de um herdeiro, mas, por fim, registravam como se a compra fosse da área total de todos os herdeiros; 3) aqueles que não vendiam sua terra, muitas vezes ficavam cercados por grandes propriedades e sofriam diversos tipos de pressão, que iam desde fechamento da saída da propriedade, até a invasão paulatina de parte de sua terra (Idem, 1988 e 2008).

Essas formas fraudulentas de acumulação e expropriação remetem ao conceito de "acumulação por espoliação,” proposto por Harvey (2004, p. 120-121), ao analisar as formas contemporâneas de acumulação. Para este autor, traços característicos daquelas formas de acumulação, descritas como restritas ao período da "Acumulação Primitiva do Capital" (Marx, 1985), não se extinguiriam ao longo da consolidação e expansão mundial do capitalismo, muito pelo contrário: formas de acumulação baseadas no uso de fraudes e da violência seriam intrínsecas ao capitalismo.

Mecanismos de expropriação e acumulação muito semelhantes aos descritos por Heredia também ocorreram (e ainda ocorrem) em nível nacional. O período estudado por Heredia foi marcado, nacionalmente, pelo processo de "modernização trágica” (Silva, 1999) da agricultura brasileira, que intensificou diversas formas de expropriação de pequenos produtores e alterou as relações de trabalho. Como demonstrou Silva (1999), esse processo não pode ser entendido somente como impulsionado pela lógica da acumulação do capital agroindustrial. O papel do Estado, por exemplo, foi fundamental para a sua consolidação. Por meio da análise do Estatuto da Terra (ET) e do Estatuto do Trabalhador Rural (ETR), a autora demonstra como estes mecanismos, que aparentemente poderiam representar algum avanço para os trabalhadores, no fundo regulamentaram a intensificação da exploração da força de trabalho (Idem). Na análise do processo de expropriação dos pequenos produtores alagoanos também não podemos negligenciar o papel desempenhado pelo Estado.

A incorporação das terras dos tabuleiros pelas usinas recebeu o estímulo direto do Estado, por meio do IAA e de diversos programas ${ }^{8}$ que, naquele momento, objetivava elevar a produtividade do setor e reduzir os custos da produção. Nesse contexto, foram adotadas diversas medidas que acabaram beneficiando as principais agroindústrias canavieiras do estado, dentre estas se destacam: financiamento público para a compra de terras, melhoramento genético da cana e isenção de impostos para importação de maquinários (Heredia, 2008; Lima, 2006; Mello, 2002). Essa conjuntura possibilitou uma vertiginosa expansão dos canaviais alagoanos, sobretudo na microrregião dos tabuleiros de São Miguel dos Campos. ${ }^{9}$

No momento presente, a invasão da canade-açúcar nas áreas dos tabuleiros está consolidada. O fato de a atual usina líder nordestina em produção de cana, situada no município de Coruripe, ter $90 \%$ de seus canaviais em terras de tabuleiros ${ }^{10}$ ilustra bem esse processo. Mas engana-se quem imagina que, após a expropriação dos tabuleiros, tenha acabado o processo de expropriação nos canaviais alagoanos, pois os trabalhadores continuam sendo expropriados pelas usinas seja em canaviais das terras planas, das várzeas encharcadiças, ou das encostas de grotas e serras. Nessa agroindústria, o trabalho não pago assume taxas altíssimas. A acumulação por espoliação não se realiza, apenas, quando a terra é espoliada do pequeno produtor, mas continua em cada metro cortado subtraído do salário do cortador de cana, em cada caso de "canguru" ou "birôla", ${ }^{11}$ decorrente do excesso de trabalho para atingir as metas

${ }^{8}$ Dentre os principais programas do Estado nesse período estão: 1) Plano de Expansão da Agroindústria Canavieira (1963); 2) Programa de Racionalização de Agroindústria Canavieira (1971); 3) Programa Nacional de Melhoramento da Cana-de-açúcar (1971); 4) Programa Nacional do Álcool (1975). Para uma leitura detalhada dessas políticas, ver Lima (1998).

${ }^{9}$ É válido ressaltar que essa expansão também provocou destruição da vegetação nativa dos tabuleiros.

${ }^{10}$ Conforme depoimento do chefe do setor de recursos humanos da referida usina. Entrevista realizada no dia 21 de março de 2013, no município de Coruripe/AL.

11 "Canguru" e "birôla" são expressões regionais cunhadas pelos canavieiros em Alagoas e São Paulo, respectivamente. Significam o momento em que, em razão dos altos níveis de sudorese, provocados pelo calor, eles são acometidos por câimbras por todo o corpo, podendo, até mesmo, levá-los, em alguns casos, à morte, como ocorreu a 23 trabalhadores no período de 2004 a 2011 em São Paulo. 
mínimas diárias de produtividade, em cada trabalhador demitido por ter a sua força de trabalho desgastada prematuramente.

\section{ACUMULAÇÃO POR ESPOLIAÇÃO NAS FLORESTAS DE BABAÇU MARANHENSES EA TERRITORIALIZAÇÃO DO CAPITAL}

Outro exemplo de acumulação por espoliação, embora fora das fronteiras geográficas da produção canavieira, porém dela resultante, reportase à destruição das florestas de babaçu no sudoeste maranhense. Em pesquisa levada a cabo nessa região em 2007, ${ }^{12}$ constatou-se um processo de expropriação de camponeses que aí viviam na condição de ocupantes, rendeiros e moradores, por meio de toda sorte de violência. Ademais da coleta dos depoimentos com homens e mulheres (70 depoentes), foram analisados 85 processos jurídicos movidos por camponeses expulsos de suas terras por meio do uso da violência e ameaças de morte, muitos dos quais passaram a viver nas periferias de Timbiras e Codó, cidades maranhenses, hoje fornecedoras de mão de obra para as usinas de São Paulo. Analisando os processos jurídicos movidos por 85 camponeses expropriados em 2004 nos municípios de Coroatá, Timbiras e Codó, constatou-se que essas famílias eram constituídas de moradores que pagavam a renda em produto ao dono da terra. Plantavam arroz, feijão, milho, mandioca e frutas. Além disso, viviam da economia extrativista do coco babaçu, atividade essencialmente desenvolvida pelas mulheres. Viviam em casas de taipa cobertas de folhas da palmeira do babaçu. No ano de 2004, homens armados desalojaram 100 famílias da Fazenda São Raimundo, pertencente a José Ribamar Thomé. Os homens eram mandantes de Ricardo Reis Vieira, que, por intermédio de escrituras falsas, afirmava ser o legítimo proprietário da terra. Segundo relatos de camponeses, a queima das casas foi feita pela Empresa do Grupo Maratá, que possui negócios relaciona-

${ }^{12}$ Pesquisa financiada pelo CNPq e coordenada por Maria Aparecida de Moraes Silva. dos ao comércio, agricultura e indústria no Nordeste. No Maranhão, esta empresa possui extensas áreas com pecuária.

Os camponeses não resistiram a este ato de violência, pois, caso contrário, seriam mortos, segundo vários depoimentos. Muitos ainda não recorreram à Justiça em razão do medo de represálias por parte da empresa expropriadora. Ademais da expropriação, a empresa destruiu as florestas de babaçu por meio de máquinas e do fogo. Em seguida, foi semeado capim para o gado. $\mathrm{O}$ fogo representa o apagamento dos vestígios, das marcas da cultura e do modo de vida. Por esta razão, trata-se de uma prática empregada pelos pistoleiros sob o mando das grandes empresas e dos latifundiários. Quanto aos camponeses expropriados de outra fazenda, denominada Campestre, de 40 mil hectares, os depoimentos revelam que a violência, além da destruição material e até mesmo impingindo a morte aos camponeses, produz-lhes o medo, cuja durabilidade impede a ação de resistência, em muitos casos. No caso dessa fazenda, em razão do movimento de resistência, uma área de 14.402 hectares foi desapropriada pelo INCRA e o Assentamento em 2007 estava se iniciando (Silva, 2010).

Esses fatos são fundamentais para a compreensão do processo de acumulação por espoliação, tendo em vista que a maioria dos camponeses expropriados se transforma, de um dia para outro, em migrantes e cortadores de cana em São Paulo. Por outro lado, as áreas, antes destinadas à pecuária do estado de São Paulo, em virtude do aumento da renda da terra, são vendidas ou arrendadas para a produção de cana, por meio do movimento de territorialização do capital, no qual “[...] o gado paulista sobe, enquanto os homens do nordeste descem" (Silva, p. 77-78, 2008).

No que tange, ainda, ao processo de territorialização, observa-se que, com a instalação de usinas, sobreleva-se o preço das terras, e até mesmo a impossibilidade de muitos pequenos proprietários se dedicarem a outras atividades agrícolas, forçando-os ao arrendamento ou à venda das mesmas. Em estudo recente, Melo (2012) constatou que muitos sitiantes da região nordeste do es- 
tado são obrigados a isso, em virtude de problemas como a proliferação da "mosca do estábulo"; o abandono da manutenção das estradas rurais pela usina durante os períodos de entressafra; os problemas causados às pequenas propriedades vizinhas às plantações de cana, cujos pastos são afetados tanto pelo depósito de poeira como do agroquímico que é aplicado nos canaviais para maturação do cultivo e que, ao atingir os pastos, tem o efeito de secá-los. Com o pasto comprometido, o gado perdendo peso e diminuindo os rendimentos obtidos com o leite ou com a carne, muitos sitiantes se viram forçados a arrendar sua pequena propriedade.

\section{A(NOVA) MORFOLOGIA DO TRABALHO}

As reflexões à luz da crítica do "desenvolvimento sustentável” da produção sucroenergética brasileira, a partir de nossos achados de pesquisa em São Paulo e Alagoas, conduzem-nos, igualmente, a outro viés crítico referente às relações de trabalho. Para esse intento, incorporamos alguns estudos realizados em outros países, a fim de aprofundar a compreensão da lógica da acumulação do capitalismo contemporâneo globalizado.

Ao cotejarmos a realidade brasileira com de das condições de moradia (Grammont; Flores, 2010). Há, assim, impedimento da vida em família, haja vista que o contrato é individual, além do controle policial exercido sobre os imigrantes para que retornem aos seus lugares de origem no final do contrato.

O dossiê da Revista Regiones (2012), publicada na Espanha, sob o título Mercados de trabajo en la agricultura mediterrânea, reúne artigos que tratam das questões acima analisadas nas plantações de hortaliças e morango nas regiões de Murcia e Andalucía. A produção é destinada à exportação para os demais países europeus. Empregam-se basicamente imigrantes - as mulheres são em maioria - provenientes do Leste Europeu, da África Central, Marrocos, Equador e Bolívia. As relações de trabalho nessas plantações, segundo os autores, segue o modelo californiano, isto é, precariedade combinada ao avanço tecnológico e à reestruturação produtiva (Cánovas, 2012, p. 1620). Essas imigrações são ordenadas e as contratações em geral são feitas na origem. O governo espanhol, visando resolver os problemas da demanda de mão de obra, em 2000, implantou o sistema de Contratação na Origem, pelo qual os países da Europa do leste eram os principais fornecedores de trabalhadores para a região de Andalucía. Em 2007, os maiores fluxos eram provenientes de Marrocos. A investigadora Reigada (2012, p. 22-26) mostra que a preferência por mulheres marroquinas deu-se em virtude de se tratar de uma força de trabalho mais barata. No entanto, no período de 2008 a 2010, em razão da crise econômica na Espanha e o regresso de famílias andaluzes ao campo, houve a diminuição da presença do número de imigrantes marroquinos e subsaarianos. Para os empresários, governo e representantes sindicais, esse modelo de imigração ordenada e temporária é o ideal, pois evita a presença dos ilegais e resolve a questão da demanda de força de trabalho nessas plantações.

A política estatal de Contratação na Origem é uma forma evidente de controlar o quantum de trabalhadores necessários à execução de tarefas temporárias, por meio de critérios seletivos como gê- 
nero, etnia, idade e, também, garantir o retorno ao país de origem após o final dos contratos de trabalho. No caso das mulheres, há a preferência por aquelas com filhos, pois o retorno ao país de origem é mais garantido, em razão do reencontro com os filhos, vis-a-vis os empresários espanhóis. Reigada (2012, p. 25) critica a imagem e o discurso dos empresários de que a Contratação na Origem, com a obrigatoriedade de firmar o compromisso de retorno, se apresente sob uma "gestão ética e humana da imigração".

Por outro lado, a pesquisa de Rodriguez (2011) revela o papel de outro agente importante neste processo de regulação, o sindicato. Nas plantações de frutas catalãs, o sindicato agrícola Unió de Pagesos é o responsável pelo recrutamento de trabalhadores imigrantes na origem e também pelo controle despótico exercido sobre os mesmos nos alojamentos nas áreas agrícolas da Catalunha. A autora, baseando-se nas reflexões foucaultianas, desenvolveu uma singular pesquisa etnográfica nos alojamentos, concluindo que os encarregados, nomeados pelo sindicato para exercerem o controle e a disciplina, assemelham-se aos capatazes de escravos da época da Roma antiga. Na verdade, o ajuntamento dos imigrantes nos alojamentos cria as condições para o exercício do poder coletivo sobre eles, tornando-os dóceis e domesticados para a aceitação das regras impostas pelos empresários. Os alojamentos se assemelham às prisões, onde ocorre a "gestão fordista dos homens", produzida pelo Sindicato. Essa autora se refere ao alojamento como exemplo de Instituição Total descrita por Goffman. ${ }^{13}$ Para aqueles que resistem, a única saída é a fuga, transformando-se em ilegais, sujeitos à perseguição policial. Caso sejam aprisionados, antes de serem extraditados para seus países de origem, são submetidos às leis do estatuto do estrangeiro irregular, pelas quais são enviados a tra-

${ }^{13}$ A análise dos alojamentos como forma de controle e disciplina da força de trabalho no tempo de trabalho e de não trabalho foi realizada por Menezes (2002) para o caso dos trabalhadores migrantes do Estado da Paraíba em usinas do Estado de Pernambuco. Análise similar foi elaborada por Cover (2011) para alojamentos de trabalhadores migrantes paraibanos em usinas da Região de Campinas e Piracicaba, Estado de São Paulo. balhos forçados nos setores produtivos menos rentáveis da economia. Assim, essas práticas, aprovadas pelo Parlamento Europeu, resultam da debilidade do estado Social e Democrático de Direito imperante na Espanha. Com isso, o Estado elimina a figura do estrangeiro nômade, que circulava em busca de trabalho nos municípios frutícolas, cerceando o direito de ir e vir consagrado na Constituição burguesa desde a Revolução Francesa nos finais do século XVIII.

Cada vez mais essas normativas vão se configurando como um fenômeno global. Outro país onde a regulação das relações de trabalho pelo estado tem sido posta em prática nas últimas décadas é o México. Vários programas foram assinados entre os governos do México, EUA e Canadá, tais como: H2-A (entre México e EUA); o Programa de Trabalhadores Agrícolas Temporários - PTAT -, firmado entre México e Canadá em 1974 (Binford et. al., 2004). Contrariamente ao que ocorre com as migrações desreguladas internas e as indocumentadas aos EUA, as migrações para o Canadá são estritamente reguladas para impedir desajustes entre oferta e procura de mão de obra. Diferentemente do Programa Bracero (1942-1964) entre México e EUA, cujas falhas ocorreram em razão da deserção dos trabalhadores, o Programa com o Canadá possui as seguintes características: retorno da maioria dos imigrantes a seus locais de origem; provimento da agricultura canadense de mão de obra barata, flexível e temporária (Quintana, 2003, p. 1). Trata-se, portanto, de uma imigração controlada e temporária, cujo crescimento foi expressivo com o passar dos anos. Esse mercado de trabalho não somente é regulado quantitativamente, como, também, por meio de critérios seletivos relativos ao gênero e etnia. As mulheres viúvas e mães solteiras são as preferidas pelos empresários canadenses, sem contar a discriminação que homens e mulheres sofrem pelo fato de desconhecerem os idiomas francês ou inglês e por não serem brancos. O processo de trabalho é rigorosamente controlado; as condições de trabalho são marcadas pelo desgaste físico em razão da postura corporal, pois recolhem o morango agachadas ou sentadas 
no chão durante jornadas de 10 a 12 horas por dia. Nos alojamentos, há o controle de hábitos, moral e sexualidade (Quintana, 2006). Após o trabalho de três a cinco meses, os (as) trabalhadores (as) são obrigados (as) a retornar aos seus locais de origem para, em seguida, imigrarem no ano seguinte, configurando-se, assim, a imigração permanentemente temporária. Em razão do tempo de duração desse fenômeno, há, por parte dos empresários, a preferência pelos (as) mesmos (as) trabalhadores (as), cujas condutas lhes são condizentes, selecionando-os (as) pelos respectivos nomes. Esse é mais um fator para a garantia da oferta de trabalho, segundo suas necessidades, sem, contudo, arcarem com os custos de reprodução dessa força de trabalho, haja vista que esses homens e mulheres não possuem os mesmos direitos sociais e laborais vigentes no Canadá.

Flores (2008) mostra que a ação sindical é praticamente nula no processo migratório no México. Ademais, no mesmo estudo, a autora questiona a existência do trabalho decente no México, mostrando, ao contrário, que lá predominam traços de vulnerabilidade, precarização e eterna circulação nacional e internacional de trabalhadores para os enclaves agroalimentares globais.

Outros autores têm demonstrado que o modelo de agricultura intensiva de exportação continua sendo considerado como elemento de desenvolvimento e modernização (Ramirez e Olaizola, 2012, p. 5), ao mesmo tempo em que oculta as transformações nas cadeias agrícolas globais e suas consequências em diferentes âmbitos: a estrutura do mercado de trabalho, a relação com o território, os movimentos migratórios e as formas de organização da vida social.

As referências, ainda que incompletas, da realidade laboral de outros países, reforçam o argumento de que a lógica da acumulação do capitalismo contemporâneo é a mesma nos diferentes países, ainda que as particularidades históricas sejam diferentes. Assim sendo, notamos que o princípio da contratação na origem dos trabalhadores migrantes é fundamental para garantir a força de trabalho imigrante ou migrante nos enclaves produtivos, com o aval dos Estados.

No caso brasileiro, a normativa institucional que rege a contratação na origem é o Compromisso Nacional para Aperfeiçoar as Condições do Trabalho na Cana de Açúcar, firmado em 2009 pelo governo federal, representantes dos trabalhadores rurais e das usinas. Este documento revela que, nos canaviais brasileiros, se estabelece o controle do mercado de trabalho e da gestão das relações de trabalho pelo estado e pelas empresas, consubstanciando-se o declínio do poder sindical. Pelo Compromisso, a fiscalização das relações de trabalho cabe às próprias empresas, retirando dos representantes dos trabalhadores essa função, haja vista que, sequer podem adentrar os locais de trabalho sem credenciamento ou prévia autorização dos patrões, buscando soluções conjuntas para possíveis problemas. Consubstancia-se, assim, o rearranjo das relações de força e dos conflitos, caracterizado não somente pelo enfraquecimento do poder dos sindicatos, mas, também, pela desconstrução dos conflitos de classe, agora tratados em mesas de diálogos e de negociações tripartites. Ao invés da verticalização, observa-se a horizontalidade das relações de classe, por intermédio da fabricação de novas matrizes discursivas e novas práticas. E mais ainda: esse "modelo" horizontal deveria servir de exemplo para outros países da América Latina produtores de açúcar e etanol.

$\mathrm{O}$ item referente à contratação na origem corrobora o controle do mercado laboral pelas empresas e impede que as famílias dos trabalhadores também migrem, posto que o contrato é individual. Após serem selecionados, os trabalhadores são transportados pelas usinas e destinados aos alojamentos (nas áreas da cana) ou nas chamadas “casas da usina” (nas cidades), onde a presença das famílias é proibida.

Uma vez apresentado o debate sobre as relações de trabalho no contexto da agricultura globalizada, retomaremos o caso brasileiro para dar visibilidade aos trabalhos desenvolvidos em diversas frentes nos canaviais paulistas e alagoanos. Tanto o modelo de agricultura intensiva de exportação, como a nova “ideologia do etanol” brasilei- 
ra, reforçam, em seu discurso, o uso intenso de alta tecnologia nos maquinários empregados nos campos. No que diz respeito ao emprego das máquinas para o corte de cana-de-açúcar, em ocasião da entrevista com o gerente de usina de álcool do interior paulista, foi possível identificar o discurso do elevado emprego de maquinaria na colheita da cana-de-açúcar, como pode ser verificado nas linhas que seguem:

Lúcio: Pensando no tema do corte manual, a gente vê que cada vez tem menos cortadores de cana.. Cleiton: ${ }^{14}$ A tendência é acabar. Acabar não. Ano que vem, provavelmente, a maioria das usinas estarão 100\% mecanizadas. Nós vamos ser mesmo uns dos que vai estar. Ou até a partir de agosto, $100 \%$ mecanizado (...). A tendência é essa, a mão de obra está muito difícil e caro de se trabalhar. Qualquer coisinha o pessoal faz greve aqui, greve ali... E outra coisa, tem que respeitar as NRs $31,{ }^{15}$ as leis trabalhistas... Então hoje é mecanização. E outro fato: não vai poder queimar. Pode queimar só as canas que você já tinha antiga. Você faz uma programação, manda pra Secretaria do Meio Ambiente, pede autorização pra queimar. Nós não fazemos nada sem autorização do Meio Ambiente. Nada. Tem que pedir antecipada a autorização com 72 horas, eles liberam, você tem que ver temperatura, umidade relativa do ar... Então é uma coisa bem criteriosa (Entrevista realizada em julho de 2012, no escritório de uma usina na região de Fernandópolis/SP).

No transcorrer da narrativa do gerente da usina, fica claro, não só o discurso da colheita totalmente mecanizada, como, também, a preocupação com a questão ambiental, que levaria a empresa a tomar a decisão de interromper o corte manual de cana-de-açúcar. Entretanto, no mesmo trecho destacado de sua narrativa, é possível encontrar outras justificativas que passam pela questão financeira e os custos de se manter uma quantidade grande de trabalhadores, fazendo cumprir as legislações trabalhistas. Em outro momento da conversa, o gerente da usina afirma que, segundo cálculos realizados pela empresa, o trabalho mecanizado representa uma economia de três a quatro reais

${ }^{14}$ Os nomes das pessoas entrevistadas durante a pesquisa de campo que são citados nesse texto são fictícios.

${ }^{15}$ Norma Regulamentadora 31 - Dispõe sobre a segurança e saúde no trabalho na agricultura, pecuária, silvicultura, exploração florestal e aquicultura. por tonelada quando comparado ao corte manual da cana. Na narrativa de Cleiton, os trabalhadores empregados na colheita manual são invisibilizados, assim como os migrantes:

Lúcio: Tem outra coisa que a gente queria saber: os cortadores de cana não estão mais encontrando trabalho e a gente queria saber se essa migração diminuiu ou se eles continuam migrando, mas agora para outras atividades.

Cleiton: Olha, eu posso falar da nossa região. Nós temos três municípios que trabalham com a gente. O operador, esse pessoal que tá no corte aí, é pessoal da região, pessoal antigo que está aqui com a gente.

Lúcio: Ah, é pessoal daqui mesmo da região. Tem essa característica, então?

Cleiton: É. Não temos ninguém de fora. (Entrevista realizada em julho de 2012, no escritório de uma usina na região de Fernandópolis/SP).

Os migrantes empregados no corte manual de cana-de-açúcar não são os únicos a serem invisibilizados no contexto do "desenvolvimento" promovido pelo agronegócio sucroenergético, o trabalho das mulheres também é ocultado nesse setor. Esse contexto tem sido apresentado e denominado por Silva (2011) como o "trabalho oculto das mulheres nos canaviais”. Entre outras reflexões, a autora mostra que as mulheres têm sido alijadas do trabalho no corte manual da cana-deaçúcar. Muitas delas estão empregadas em atividades que são ainda mais invisibilizadas que aquelas realizadas pelos homens nos eitos dos canaviais. Muitas das mulheres que são expulsas do corte manual de cana-de-açúcar permanecem no setor canavieiro, sendo empregadas como "faxineiras dos canaviais" (Silva, 2011, p. 28), em atividades como a bituca, abrir eito e o recolhimento de pedras nos canaviais. Bituqueiras são as trabalhadoras que recolhem, no chão, os restos da cana deixados após o corte manual e o carregamento pelo guincho. As mulheres trabalham em dupla, carregando as "bitucas" de cana para a "rua do monte", de onde serão levadas para a usina. "Abrir eito significa cortar as fileiras de cana que estão sobre as curvas de nível - sulcos feitos para a drenagem das águas fluviais - antes da utilização das máquinas, pois estas só cortam as canas em terras planas" (Silva, 
2011, p. 26). As mulheres empregadas na "pedra” também fazem a limpeza do canavial, retirando as pedras do campo para que as máquinas colheitadeiras de cana possam passar pelo terreno sem obstáculos.

Há, ainda, outras atividades nos canaviais paulistas que são camufladas no discurso da "ideologia do etanol", que destaca somente o emprego de tecnologias elaboradas. Dentre as tarefas realizadas manualmente nos canaviais, podemos citar: a retirada de cercas e divisões de currais de propriedades arrendadas recentemente para o plantio de cana-de-açúcar, ${ }^{16}$ aplicação de veneno utilizando bomba-costal para eliminar as casas de formigas nos canaviais, aplicação de veneno "mata-mato" para eliminar o colonhão e o cipó, ${ }^{17}$ plantio e carpa de árvores plantadas pela usina em áreas de reflorestamento. A realização dessas atividades está inserida em um contexto hierárquico, na medida em que as trabalhadoras e os trabalhadores encarregados de executar as tarefas manuais não recebem os mesmos direitos que as demais categorias de trabalhadores da usina - aqueles são excluídos, por exemplo, do convênio médico pago pela empresa com uma cooperativa de saúde, além de receber o "vale alimentação" com valor inferior ao dos demais trabalhadores. Outras irregularidades persistem na execução das atividades manuais:

Os trabalhadores da Turma do Veneno realizam suas refeições vestidos com as mesmas roupas com as quais aplicam os herbicidas, o que apresenta nítidos riscos de contaminação. As turmas do trabalho manual cumprem um regime de trabalho de 6X1 (trabalham de segunda a sábado, e folgam apenas aos domingos), enquanto todas as outras categorias cumprem um regime de trabalho de 5X1. Sendo o trabalho agrícola manual praticamente o único para o qual mulheres são contratadas (em menor número também trabalham no Posto de Gasolina da Usina e no almoxarifado), e sendo as mulheres frequentemente as únicas responsáveis pelo trabalho do-

${ }^{16}$ Essas tarefas foram encontradas durante incursão em campo empírico na região de Fernandópolis/SP e descritas pela pesquisadora Beatriz Medeiros de Melo, membro da pesquisa "Novas configurações do trabalho nos canaviais. Um estudo comparativo entre os estados de São Paulo e Alagoas", coordenada pela professora Maria Aparecida de Moraes Silva, com o apoio financeiro do CNPq.

17 Tais plantas são consideradas agressivas para o desenvolvimento da cana-de-açúcar. méstico e o cuidado dos filhos, resulta que a reprodução social das famílias destes trabalhadores é prejudicada e precarizada. As consequências inevitáveis deste quadro são: (a) as mulheres ocupam todo o domingo com as atividades domésticas, não lhes restando tempo para o lazer, a sociabilidade, o acompanhamento da vida de seus filhos... (b) como as creches municipais não funcionam aos sábados, aquelas mulheres que não podem deixar seus filhos sob os cuidados de parentes ou outra pessoa de sua rede de sociabilidade e confiança, se veem obrigadas a pagar uma babá para realizar este trabalho, então, remunerado, e, desse modo, reduz-se ainda mais seus parcos ganhos. Por estas e outras razões é frequente, no discurso das mulheres, a comparação de sua situação como de "escravidão", já que "vivem para a Usina” (Trecho do diário de campo de Beatriz Medeiros de Melo, julho de 2012).

A sensação de viver como "escravo" também foi descrita pelos trabalhadores e trabalhadoras do corte manual de cana na usina onde Cleiton trabalha. Ao contrário do que diz o gerente, a maioria das pessoas empregadas no corte manual da cana é proveniente de outros estados brasileiros, como Bahia, Maranhão, Piauí e Alagoas. Muitos dos quais receberam, antes de realizar a viagem para o interior de São Paulo, promessas por parte da empresa de que ficariam em alojamentos providenciados pela usina, sem necessitar pagar as despesas com aluguel. Entretanto, quando chegaram à região de Fernandópolis se depararam com outra realidade. Muitos despendem um valor de aproximadamente 250 reais para viver em uma residência com instalações bastante precárias, sem camas, com espaço bastante reduzido.

Na ocasião em que as entrevistas foram realizadas, em julho de 2012, encontramos algumas turmas em greve em razão das inúmeras irregularidades encontradas na execução da atividade. Uma das trabalhadoras nos apresentou o seguinte relato: "o povo diz que a escravidão acabou, mas ainda não acabou”. A caracterização do trabalho como escravidão se dá não só pelo fato de a remuneração ser bastante reduzida (na safra de 2012 a turma chegou a receber apenas seis centavos pelo metro de cana cortada; em outros períodos a turma recebeu de nove a doze centavos pelo metro da cana embolada), mas, também, pela forma 
desumanizadora como os fiscais tratam os trabalhadores e as trabalhadoras, comparando-os com animais. Na imagem do recibo (Figura 1) de uma das trabalhadoras empregadas no corte manual de cana-de-açúcar é possível visualizar o valor extremamente reduzido pago pela metragem da cana. Há dias em que a trabalhadora recebeu apenas $\mathrm{R} \$$ 7,00 .

Figura 1 - Recibo com o valor da metragem da cana e quantidade colhida

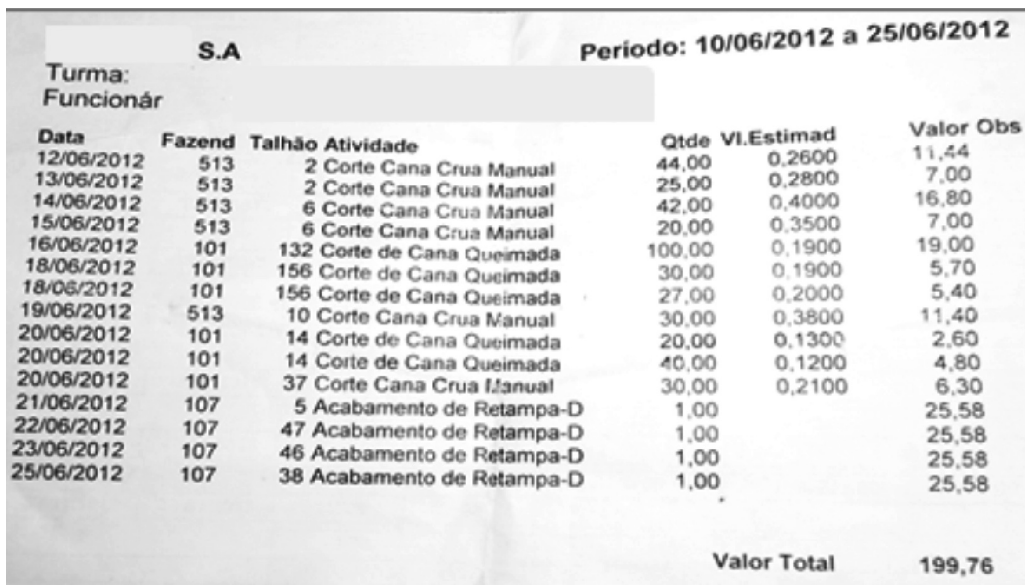

(Imagem captada durante pesquisa de campo na região de Fernandópolis/SP, em julho de 2012)

Os trabalhadores grevistas denunciaram, ainda, as seguintes irregularidades: preço reduzido do vale-alimentação (60 reais por mês); a empresa fazia descontos salariais e do vale-alimentação mesmo quando a falta do trabalhador era justificada com atestado médico; alguns trabalhadores tinham que iniciar o corte da cana poucos minutos após a queima do canavial, o que implicava a realização do labor sob um calor extremamente excessivo. Em razão da intensa mecanização, é possível constatar que as melhores plantações são destinadas às máquinas. Por sua vez, as canas que estão "deitadas", desalinhadas, que crescem na curva de nível são destinadas aos homens e mulheres que têm ao seu lado somente o facão para "enfrentar" tal atividade, que os suga física e emocionalmente-ao contrário do "palco" preparado para a atuação das máquinas, que passam pelos canaviais planos, com o terreno livre das pedras que as mulheres recolheram anteriormente.

Tamanha intensificação e exploração da for- ça de trabalho (Silva, 1999, 2004 e 2011; Alves, 2007; Verçoza, 2012) ocasionaram inúmeros acidentes de trabalho e doenças advindas da atividade no corte manual da cana. Um dos trabalhadores relatou a ocasião em que se feriu gravemente ao cortar o próprio dedo com o facão e recebeu por parte da empresa um atendimento após horas de sangramento. Ao receber o atendimento, seus colegas relataram ao enfermeiro da usina o que tinha acontecido e que o sangramento estava muito intenso. Ao ver o desespero do trabalhador e seus colegas, o enfermeiro lhes disse: "Cortou o dedo, não foi a cabeça".

O descaso com problemas de saúde ocasionados pela atividade também foi relatado por uma das trabalhadoras: após realizar um exame em razão de dores intensas na coluna e levar o resultado para o médico, recebeu como resposta a seguinte sentença: "você vai morrer com esse desvio na coluna”, sem receber a recomendação de qualquer tipo de tratamento ou encaminhamento a um afastamento por doença adquirida no trabalho.

Durante a realização do corte manual da cana-de-açúcar, muitos trabalhadores são acometidos pela chamada "câimbra de nó" ${ }^{18} \mathrm{Um}$ dos trabalhadores apresentou a seguinte descrição da sensação provocada pela câimbra de nó: "a dor vai entrando pelo pé e aos poucos vai subindo por dentro do corpo como se fosse um inseto. Eu sinto como se tivesse um bolo se formando no estômago, por isso chamam de câimbra de nó". Um deles sentiu uma câimbra intensa durante o corte e percebeu que "a morte estava perto e que ela tinha uma cara feia”. Seus colegas interromperam o trabalho, solicitando que ele fosse levado para o hospital, mas isso não aconteceu. Alguns dos trabalhadores estiveram presentes nos canaviais em ${ }^{18}$ Outra expressão para se referir às câimbras, além das do "canguru" e "birôla". 
outros municípios paulistas quando colegas de trabalho faleceram no eito do canavial após sentir a "câimbra de nó". Um deles acompanhou um colega que perdeu a vida em 2010 no município de Monte Alegre: ${ }^{19}$ "meu colega foi encontrado em pé, morreu abraçado com a cana”.

Em meio às narrativas que demonstravam a situação de humilhação no ambiente de trabalho, o tratamento desumanizado era o fio condutor da conversa. Esse teor ficou bastante claro quando as seguintes frases apareceram: "a ordem é acabar com o povo"; "O sonho foi entrando por água abaixo”; “O ‘gato’ da usina só quer que a gente morra”; “A usina só quer ferrar o pobre"; "Ninguém aqui é escravo, ninguém aqui é bicho”.

O cenário de humilhação e desrespeito é configurado, também, a partir da relação que se estabelece com os fiscais de turma. Um dos trabalhadores contou que o fiscal de turma os tratava de forma bastante hostil, exigindo que intensificassem o ritmo da produção. Esse mesmo fiscal ameaçou um trabalhador maranhense de morte, dizendo a ele que, se não trabalhasse direito, voltaria para sua terra "com o paletó de madeira”.

Assim, os elementos apresentados pelos trabalhadores e trabalhadoras, tais como a elevada exploração da força de trabalho, o tratamento desumano, a humilhação nos eitos de cana e a comparação com animais e escravos, nada disso parece combinar com a imagem de grandeza e a "sustentabilidade" que caracterizam o "desenvolvimento" gerado pelo setor sucroalcooleiro. Nas próximas linhas, recorreremos à realidade dos canaviais alagoanos para trazer mais experiências que destoam da grandeza da "ideologia do etanol".

No tocante aos canaviais de Alagoas, na safra 2012/2013, a agroindústria canavieira alagoana contou com o uso de 50 máquinas colheitadeiras (todas operando em parte das terras planas dos tabuleiros). ${ }^{20}$ O processo de mecanização do corte encontra-se em fase embrionária quando comparado ao de São Pau-

${ }^{19}$ No município de Monte Alegre a média mínima que cada trabalhador deveria cortar por dia era de 12 toneladas e meia de cana.

${ }^{20}$ Conforme informação concedida pelo coordenador de planejamento e administração rural de uma usina loca- lo. ${ }^{21} \mathrm{O}$ plantio de cana em vastas áreas de topografia acidentada - sobretudo no norte do estado - é um dos fatores que dificulta (ou inviabiliza) um maciço processo de mecanização da colheita em curto prazo. Em algumas dessas áreas, consideradas até o momento como inacessíveis às modernas máquinas colheitadeiras (guiadas por GPS, equipadas de ar condicionado e movidas com tração por esteiras), ainda transitam burros e mulas carregando cana (guiados por cambiteiros, que se abanam com o chapéu, e movidos por tração animal). O cambiteiro é o trabalhador "que vem com um burro com cangalha, eleva a cana até onde o caminhão está, e depois o caminhão leva para a usina”.22

O serviço de cambitagem, que, com a decadência dos engenhos, parecia condenado à extinção, continua usual em algumas encostas de Alagoas. Como um transporte que ainda requer amarração de feixes de canas cortadas, que, em cada viagem até o caminhão, leva apenas aproximadamente entre 20 e 30 feixes de cana no lombo do burro (em torno de no máximo 100 kg de cana) pode sobreviver na contemporaneidade? Talvez (a) (o) leitor (a) imagine que esse tipo de transporte sobreviva no século XXI por ser essa cana destinada a alguma produção artesanal de cachaça, à produção de uma mercadoria inserida em um pequeno mercado deveras específico, que, por não encontrar concorrentes, seria competitiva. No entanto, não é disso que se trata. A cambitagem em questão não leva a cana para um engenho que produz alguma cachaça especial, ela transporta parte da cana que é esmagada por uma usina de médio porte de Alagoas. ${ }^{23}$ A cana transportada nesse serviço de cambitagem é transformada em açúcar para ser ex-

lizada na região dos tabuleiros de São Miguel dos Campos, em entrevista realizada no dia 21 de março de 2013.

${ }^{21}$ Segundo estimativa do Sindaçúcar/AL, em 2011 o corte mecanizado correspondia a $20 \%$ da colheita de cana alagoana (Padilha, 2011), enquanto em São Paulo, de acordo com a União da Indústria da Cana de Açúcar (UNICA), mais $60 \%$ da colheita já era mecanizada no mesmo ano.

22 Conforme relato de Iracema, no município de Ibateguara/ AL, em 14/06/2012, durante entrevista concedida para a equipe da pesquisa, "Novas configurações do trabalho nos canaviais. Um estudo comparativo entre os estados de São Paulo e Alagoas", mencionada na nota 15 deste artigo.

${ }^{23}$ A referida usina fica localizada na Microrregião Serrana do Quilombo dos Palmares, área marcada pela grande 
portado para países de outros continentes, vira do um bolo de cana cada vez mais pesado. Próxiálcool, que é vendido nos postos de combustível. mo ao pé do morro o esforço é ainda maior. A

Além do trabalho de cambitagem - que é embolada termina quando o bolo de cana chega ao requisitado em áreas de difícil acesso, onde nem a local acessível para os animais ou máquinas. Após máquina carregadeira de cana e nem o caminhão o término da embolada, o trabalhador sobe o mor-

Figura 2 - Embolamento da cana

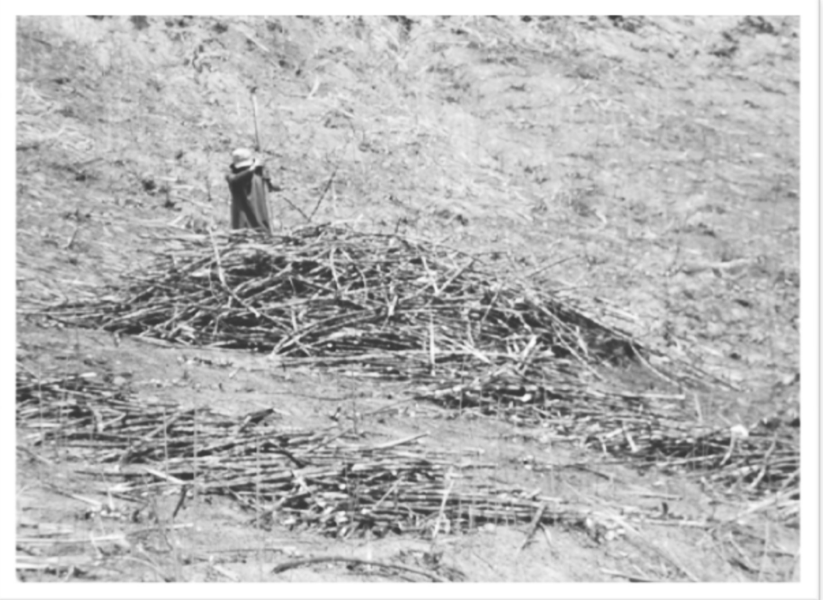

Imagem captada durante pesquisa de campo em Ibateguara/AL, 21 de janeiro de 2013. Foto: Lúcio Verçoza.

se aproximam -, existe, nas encostas mais íngremes, a embolada da cana. Esse serviço consiste em emaranhar as canas que foram cortadas por outros trabalhadores para rolá-las ladeira abaixo, de modo que elas cheguem até uma área que possa ser acessada por máquinas carregadeira ou por animais de tração. Para tal tarefa, o trabalhador utiliza um longo cabo de madeira que serve como alavanca para levantar as canas, que se amontoam cada vez mais a cada levantada. A atividade consiste em se agachar, colocar o cabo de madeira embaixo do monte de canas, e puxar o cabo para cima, de modo que o monte de cana seja empurrado para baixo. À medida que o trabalhador segue avançando morro abaixo, vai se formanro para embolar mais cana. A jornada de trabalho segue em desce e sobe, em agacha e levanta, em puxa e empurra. Esse ciclo se repete até acabarem as canas de embolada.

Em pesquisa de campo realizada em Ibateguara, município localizado ao norte de Alagoas, pudemos acompanhar o dia de trabalho de uma frente de corte, transporte e carregamento da cana. ${ }^{24} \mathrm{Os}$ canaviais queimados estavam em morros imensos, alguns trechos eram tão íngremes que, como bem expressou um trabalhador canavieiro: "para subir a rampa, tem que subir de quatro, tem quadra que aconteceu isso, que o trabalhador não tem condições de subir cortando, que é mui-

Figura 3 - Frente de corte manual nos morros em Ibateguara/AL

quantidade de morros e serras. Durante a pesquisa de campo, uma trabalhadora nos informou que todas as fazendas da usina possuem criação de burros. Um morador de uma das fazendas da usina nos relatou que o serviço do cambiteiro é desempenhado por alguns trabalhadores canavieiros específicos que são deslocados para cambitagem quando existe necessidade desse serviço.
${ }^{24}$ A referida pesquisa de campo ocorreu no dia 21 de janeiro de 2013, no âmbito da pesquisa "Novas configurações do trabalho nos canaviais. Um estudo comparativo entre os estados de São Paulo e Alagoas", mencionada na nota 15 deste artigo. 
to alto”. ${ }^{25} \mathrm{O}$ risco de quedas era grande, não só pela inclinação acentuada ao extremo, mas, também, devido aos trechos de erosões e cortes nos morros. Em determinados casos, essas erosões podem ultrapassar 4 metros de altura. Alguns cortadores de cana nos falaram de amigos que já se machucaram em quedas nesses paredões. Os canaviais se estendem até à beira dessas aberturas. Nessas condições, é preciso ter muito equilíbrio e perícia para manusear os facões. Além disso, não basta ter esses requisitos, é preciso cortar no mínimo 5,2 toneladas para manter-se empregado nessa usina. O calor era enlouquecedor, não havia uma sombra. O ambiente era tão hostil que tornava extenuante até a simples tarefa de subir e descer o morro acompanhando o trabalho alheio. A fuligem se misturava à poeira que se misturava ao suor. Imagine para aqueles que estavam cortando cana! Imagine para os que as embolavam!

\section{À GUISA DE CONCLUSÃO}

${ }^{25}$ Entrevista concedida por Murilo, 25 anos, no município de Junqueiro/AL, em 01/05/2012. gem do desenvolvimento sustentável dessa produção, bem como a miséria do trabalho que se esconde atrás das cortinas desse palco. Vimos, também, que essa miséria se estende a outros países, não sendo, portanto, uma exceção, porém, fazendo parte da lógica da acumulação por espoliação do capitalismo contemporâneo.

As condições de trabalho nos canaviais não podem ser simplesmente consideradas precárias, o que seria eufemismo. Consideramos o trabalho sem as máscaras "protetoras" do Estado brasileiro, signatário das Convenções internacionais do chamado "trabalho decente". Não adjetivamos esse trabalho. Apenas revelamos as cruezas de sua essência. Esse trabalho nos canaviais das grotas, morros e serras alagoanas e nos planaltos paulistas nos remete ao mito de Sísifo, personagem que foi condenado por Zeus a empurrar uma enorme pedra morro acima, porém, ao alcançar o topo, a pedra invariavelmente rolaria morro abaixo, fazendo com que o esforço de Sísifo fosse sem fim. Tanto o mito de Sísifo, quanto o labor nesses canaviais, apontam quão degradantes são determinadas formas de trabalho. No entanto, existe uma grande diferença entre ambos: enquanto o mito de Sísifo é proclamado ao longo de muitos séculos como exemplo de trabalho abominável, a imagem mascarada do labor nos canaviais brasileiros é mais uma das falácias que compõe o mito do "desenvolvimento sustentável" do etanol. Resta-nos perguntar: "Desenvolvimento" de quê? "Sustentável" para quem?

Recebido para publicação em 05 de abril de 2013 Aceito em 11 de junho de 2013

\section{REFERÊNCIAS}

ALVES, F. Migração de trabalhadores rurais do Maranhão e Piauí para o corte da cana em São Paulo. In: NOVAES, J. R; (Org.). Migrantes: trabalho e trabalhadores no complexo agroindustrial canavieiro (os heróis do agronegócio brasileiro). São Carlos: Editora da Universidade Federal de São Carlos, 2007, 314p.

ANDRADE, M. C. Os rios-do-açúcar no Nordeste orien- 
tal: IV Rios Coruripe, Jequiá e São Miguel. Publicações do Instituto Joaquim Nabuco de Pesquisas Sociais. Recife: Imprensa Oficial, 1959.

Modernização e pobreza: a expansão da agroindústria canavieira e seu impacto ecológico e social. São Paulo: Editora da Universidade Estadual Paulista, 1994, $252 p$.

ANDRADE, J. M. F. Construção de um índice de sustentabilidade ambiental para a agroindústria da cana paulista da cana-de-açúcar (ISAAC). 2009. 259f. Dissertação (Mestrado profissional). Escola de Economia de São Paulo, Fundação Getúlio Vargas, 2009.

BINFORD, L. et al. Rumbo ao Canadá. La migración canadiense de trabajadores agrícolas tlaxcaltecas. México: Ediciones Taller Abierto, 2004. 267p.

BOSSO, R. M. V. et al. Effects of genetic polymorphisms CYP1A1, GSTM1 and GSTP1 on urinary 1-hydroxypyrene levels in sugarcane workers. Science on the Total Environement. v. 370, p. 382-390, 2006.

BRUNO, R. Movimento SOU AGRO: Marketing, habitus e estratégias de poder do agronegócio. ANPOCS, 2012. Texto digitalizado.

BURKE, P. A Fabricação do rei. A construção da imagem pública do rei Luís XIV. Rio de Janeiro: Editora Zahar, 1994. 254p.

CÁNOVAS, A. P. Trabajadores y agriculturas mediterrâneas en la globalización. Regiones, Suplemento de Antropología, México, n. 47, p.16-20, jan./mar. 2012.

CARDOSO, A. A. et al. Biocombustível, o Ito do combustível limpo. Revista Química Nova na Escola, N. 28, p. 2008. Disponível em: http://qnesc.sbq.org.br/online/ qnesc28/03-QS-3207.pdf. Acesso em 30/11/2008.

COVER, M. O "Tranco da Roça" e a "Vida no Barraco": um estudo sobre trabalhadores migrantes no setor do agronegócio canavieiro. João Pessoa: Editora da Universidade Federal da Paraíba, 2011.

DE LA GARZA, E. "Conclusiones” en la formación socioeconômica neoliberal. México: Editora Plaza y Valdés, 2000 .

FLORES, S. M. L. Es posible hablar de um trabajo decente em la agricultura moderno-empresarial em México? Cotidiano, México, v. 23, n. 147, p. 25-33, enero-febrero, 2008.

(Coord). Migraciones de trabajo y mobilidad territoral. México: Editora Miguel Ángel Porrúa; Conacyt, 2010.

GRAMMONT, H. C; FLORES, S. M. L. Productive restructuring and "standartization" in México horticulture: consequences for labour. Journal of Agrarian Change, v. 10, n. 2, april, p. 228-250, 2010.

HARVEY, D. O novo imperialismo. São Paulo: Edições Loyola, 2004. 201p.

HEREDIA, B. A. Formas de dominação e espaço social A modernização da agroindústria canavieira em Alagoas. São Paulo: Editora Marco Zero; Brasília: MCT/CNPq, 1988. $467 \mathrm{p}$.

O Campesinato e a Plantation. A história e os mecanismos de um processo de expropriação. In: NEVES, D. P; SILVA, M. A. M. (Orgs.). Processos de constituição e reprodução do campesinato no Brasil. Formas tuteladas de constituicão camponesa. São Paulo: Editora da Universidade Estadual Paulista, v.1, p. 39-67, 2008.

et al. Sociedade e economia do "agronegócio" no Brasil. Revista Brasileira de Ciências Sociais, São Paulo, v. 25, n. 74, out. p. 159-176, 2010.

LEIS, H. R. A modernidade insustentável: as críticas do ambientalismo à sociedade contemporânea. Petrópolis:
Editora Vozes; Florianópolis: Editora da Universidade Federal de Santa Catarina, 1999. 261p

LIMA, A. A. A agroindústria canavieira alagoana - da criação do IAA à desregulamentação na década de 1998. Dissertação (Mestrado em Economia). Programa de Pósgraduação em Economia. FALTA ANO.

Alagoas e o complexo agroindustrial canavieiro no processo de integração nacional. Tese (Doutorado em Economia). Programa de Pós-graduação em Economia. Instituto de Economia da Universidade de Campinas, 2006.

LOUREIRO, O. Açúcar: notas e comentários. Maceió: Gráfica São Pedro, 1969.

MARX, Karl. O Capital: crítica da economia política/Livro Terceiro. São Paulo: Editora Nova Cultural, 1985.

MELLO, P. D. A. Cana-de-açúcar e reestruturação produtiva: ação sindical e os movimentos sociais rurais em Alagoas a partir de 1985. Tese (Doutorado em Sociologia). Programa de Pós-Graduação em Sociologia da Universidade Federal de Pernambuco, Recife, 2002.

MELO, B. M. História e memória na contramão da expansão canavieira: um estudo das formas de resistência do sitiantes no noroeste paulista. Tese (Doutorado em Sociologia). Programa de Pós-graduação em Sociologia da Universidade Federal de São Carlos, 2012.

MENEZES, M. A. Redes e enredos nas trilhas dos migrantes: um estudo de famílias de camponesesmigrantes. Rio de Janeiro: Relume Dará. João Pessoa: Editora da UFPB, 2002.

PADILHA, Tiago. Doce verde amargo. Traços de influência da cana-de-açúcar na sociedade de Alagoas. Brasília: Athalaia Solução Digital, 2011.

PLÁCIDO Jr; MELO, M. MENDONÇA, M. L. O mito dos agrocombustíveis. (Org.) Agroenergia: mitos e impactos na América Latina. São Paulo: Comissão Pastoral da Terra e Rede Social de Justiça e Direitos Humanos, 2007.

QUINTANA, O. B. Relación de gênero, trabajo trnasnacional y migración temporal: trabajadores $\mathrm{y}$ trabajadoras agrícolas mexicanos em Canadá. Primer Coloquio Internacional Migración y desarallo: transnacionalismo y nuevas perspectivas de integración. 23 a 25 de octubre, 2003, Zacatecas, Mexico. Disponível em pdf. http://www.migracionydesarrollo.org. Acesso em 15 de janeiro 2013

QUINTANA, O. B. Gênero, seualidade e identidade. Transmigrantes mexicanos em Canadá. II Coloquio internacional sobre Migración y desarollo. Migración, transnacionalismo y transformación social. 26-28 octubre 2006. México. Disponível em pdf: http:// www.migracionydesarrollo.org. Acesso em 15 de janeiro 2013 .

RAMÍREZ, A. S; OLAIZOLA, A. R. Mercados de trabajo en la agricultura mediterrânea. Regiones. Suplemento de Antropología, México, n. 47, jan./mar. p. 4-7, 2012.

REIGADA, A. Agricultura industrial en Andaluíca y feminización del trabajo en las cadenas agrícolas globales Regiones, año 8, n. 47, p. 22-26, 2012. http:// www.suplementoregiones.com/pdf/Regiones47.pdf. Acesso 10 de janeiro 2013.

RIBEIRO, H. Sugar cane burning in Brazil: respiration heath effects. Revista Saúde Pública, São Paulo, n. 42, v. 2, p. 370-376, 2008. Disponível em: http://www.scielo.br/ pdf/rsp/v42n2/en_6804.pdf. Acesso em 03 de dezembro 2009 .

RIBEIRO, H; PESQUERO, C. Queimadas de cana-de-acúcar: avaliação de efeitos na qualidade do ar e na saúde respiratória de crianças. Revista Estudos Avançados, São Paulo, v. 24, n. 68, p. 255-271, 2010. 
RODRIGUEZ, O. A. Reterritorializando el flujo de mano de obra extrangera: el nacimiento de uma instituición total nueva en la agricultura catalana. Geopolíticas, 2011 , v. 2, n. 2, 277- 281 .

SANT'ANA, M. Contribuição à história da cana-de-açúcar de Alagoas. Recife: Instituto do Açúcar e Álcool, Museu do Açúcar, 1970

SILVA, M. A. M. Errantes do fim do século. São Paulo: Editora da Universidade Estadual Paulista, 1999.

Produção de alimentos e agrocombustíveis no

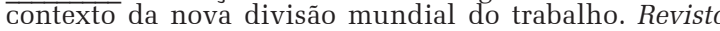
Pegada, CEGET, Presidente Prudente, v. 9, n. 1, jun., p. 63-80, 2008. Versão eletrônica: www.fct.unesp.br/ cegetPEGADA91/04-9-1.

Migrantes maranhenses nas terras paulistas. In: SILVA, S. A. (Org.), Migrantes em contextos urbanos: uma abordagem interdisciplinar. Manaus: Editora da Universidade Federal do Amazonas, p. 35-76, 2010.

O trabalho oculto nos canaviais paulistas. Pers

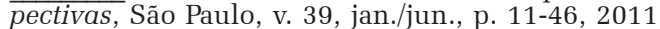

Se eu pudesse, eu quebraria todas as máquinas. In: ANTUNES, R. O Avesso do Trabalho (Orgs.), São Paulo: Editora Expressão Popular, 2004, p. 29-78.

SILVA, M. A. M.; MARTINS, R. C. A degradação social do trabalho e da natureza no contexto da monocultura canavieira paulista. Revista Sociologia, Porto Alegre, Universidade Federal do Rio Grande do Sul, ano 12, n. 24, p.196-241, maio/ago. 2010.
SILVA, M. A. M. et al. Estado e regulação das relações de trabalho no Brasil. 2013. (No prelo).

SZMRECSÁNYI, T. Tecnologia e degradação ambiental: o caso da agroindústria canavieira no estado de São Paulo. Informações Econômicas. São Paulo, v. 24, n. 10, p. $73-$ 82, out. 1994

TEIXEIRA, C. O desenvolvimento sustentável em unidade de conservação: a "naturalização" do social. Revista Brasileira de Ciências Sociais, ANPOCS, São Paulo, v. 20 , n. 59 , p. 51-66, out. 2005 .

THOMAS Jr. A. Dinâmica Geográfica do Trabalho no Século XXI”. (Limites Explicativos, autocrítica e desafios teóricos). Centro de Estudos de Geografia do Trabalho (CEGeT). Tese de livre-docência UNESP/Faculdade de Ciências e Tecnologia, Presidente Prudente, SP, 2009. http:/ /www4.fct.unesp.br/ceget/

VERÇOZA, L. V. Trabalhadores nos canaviais de Alagoas um estudo sobre as condições de trabalho e resistência. Dissertacão (Mestrado em Sociologia). Programa de Pósgraduação em Sociologia da Universidade Federal de São Carlos, 2012

XAVIER, C. V. et al. Monopólio na produção de etanol no Brasil. A fusão Cosan-Shell. São Paulo: Editora Rede Social de Justiça e Direitos Humanos, 2012. 


\section{THE IMAGE OF ETHANOL AS "SUSTAINABLE DEVELOPMENT" AND THE (NEW) MORPHOLOGY OF LABOR}

\author{
Maria Aparecida de Moraes Silva \\ Lúcio Vasconcellos de Verçoza \\ Juliana Dourado Bueno
}

The aim of this text is to analyze labor relations and conditions in sugar cane fields which have resulted from the labor reconfiguration process as related to the current situation of intensified mechanization of the sugar cane harvest. Due to the rapid changes which have occurred in the harvest, we feel that these labor relations must be analyzed within the context of the "sustainable development" image projected by sugar and ethanol companies and by the Brazilian government. Intensification of the exploitation of the work force in the setting of a (new) morphology combines highly advanced technology with increasing underqualification of the labor force. These reflections will aim to bring to the surface the social reality hidden behind the ideology fabricated to sustain this economic activity. We seek a critical analysis of the developmentalist ideology inherent to this type of production. The methodology employed is based on oral history and direct observation in the sugar cane fields of the states of São Paulo and Alagoas.

KEY WORDS: Labor relations. Working conditions. Capitalism in the fields. Sugar cane.

\section{L'IMAGE DE L'ÉTHANOL EN TANT QUE "DÉVELOPPEMENT DURABLE" ET LA (NOUVELLE) MORPHOLOGIE DU TRAVAIL}

\author{
Maria Aparecida de Moraes Silva \\ Lúcio Vasconcellos de Verçoza \\ Juliana Dourado Bueno
}

Le but de ce texte est d'analyser les relations et les conditions de travail dans les plantations de canne à sucre, suite au processus de reconfiguration du travail et au moment actuel, caractérisé par l'intensification du processus de mécanisation de la coupe de la canne à sucre. En raison de la rapidité des changements dans le processus de ce travail, il s'avèrequecesrelations de travail doiventêtreanalysées dans le contexte de l'image de "développement durable" produite par les fabriques de sucre et d'alcool et par l'Etat brésilien. Lintensification de l'exploitation de la main d'œuvre dans le cadre d'une (nouvelle) morphologie associe, d'une part, des technologies de pointe et, d'autre part, l'augmentation d'un manque de qualification de la main d'œuvre. Les réflexions faites essaient de mettre en lumière la réalité sociale qui se cache derrière une idéologie fabriquée pour soutenir cette activité économique. On cherche à faire une analyse critique de l'idéologie du développement liée à cette production. La méthodologie utilisée se base sur la tradition orale et l'observation directe dans les plantations de canne à sucre des états de São Paulo et d'Alagoas.

Mots-CLÉs: Relations de travail. Conditions de travail. Capitalisme à la campagne. Canne à sucre.

Maria Aparecida de Moraes Silva - Doutora em Sociologia. Professora livre-docente aposentada da UNESP. Professora visitante do Departamento de Sociologia da UFSCAR. Pesquisadora (1A) do CNPq. Autora, entre outros, do livro Errantes do fim do século, publicado pela EDUNESP. As linhas de pesquisa se encaixam na Sociologia Rural e na Sociologia do Trabalho Rural. Os temas versam sobre trabalho, memória, migração, gênero e raça/etnia, referentes à realidade rural do estado de São Paulo e outras regiões do país.

Lúcio Vasconcellos de Verçoza - Doutorando do Programa de Pós-Graduação em Sociologia da Universidade Federal de São Carlos. Bolsista da Fundação de Amparo à Pesquisa do Estado de São Paulo. Membro dos Grupos de Pesquisa “Terra, Trabalho, Memória e Migração” e “Trabalho e Capitalismo Contemporâneo”. Em sua dissertação de mestrado, analisou o processo de exploração-dominação do trabalho e as formas de resistência construídas pelos trabalhadores nos canaviais de Alagoas. Publicou um capítulo no livro Trabalho e Capitalismo Contemporâneo. Atualmente, se dedica ao estudo da relação entre trabalho e saúde no universo canavieiro.

Juliana Dourado Bueno - Doutoranda do Programa de Pós-Graduação em Sociologia na Universidade Federal de São Carlos. Membro do Grupo de Pesquisa Terra, Trabalho, Memória e Migração, coordenado por Maria Aparecida de Moraes Silva. Desde 2004, desenvolve pesquisa no interior do grupo na temática do trabalho rural e relações de gênero. Em sua dissertação de Mestrado pesquisou as trajetórias laborais de mulheres e homens empregados em um abatedouro de frangos no interior de São Paulo. Publicou um capítulo no livro Questão Agrária e Saúde dos Trabalhadores: desafios para o século XXI. Atualmente, desenvolve pesquisa sobre as experiências de trabalho no processo de produção de flores na região de Holambra (SP). 
